\section{PENERAPAN PEMBELAJARAN DARING DI PAUD BAITURRAHMAN DI MASA PANDEMI COVID 19}

\author{
Muhammad Holimi ${ }^{1}$ \\ 1)Institut Agama Islam Sunan Kalijogo Malang \\ 1) $\underline{\text { halimi15@gmail.com }}$
}

\begin{abstract}
Abstrak. Pada masa pandemi covid 19 ini semua lembaga pendidikan tanpa terkecuali harus melakasanakan proses belajar mengajar secara daring. Namun hal ini butuh kesiapan para guru dan para murid dalam melaksanakannya. Khususnya di Paud Baiturrahman yang merupakan lembaga pendidikan anak usia dini, merupakan tantangan yang besar dalam mendidik anak-anak melalui daring. Butuh kesiapan orang tua untuk selalu mendampingi putra-putrinya selama proses pembelajaran daring di masa pandemi covid 19. Penelitian ini bertujuan untuk mengetahui bagaimana penerapan pembelajaran daring di Paud Baiturrahman di Perum Bukit Cemara Tidar Krangbesuki Sukun Malang sebagai lembaga pendidikan di masa pandemi covid-19. Subjek penelitian ini adalah Kepala sekolah, guru dan orang tua. Data primer diperoleh melalui wawancara yang mendalam dengan subjek penelitian yang dilanjutkan dengan observasi dan dokumentasi sebagai proses awal analisis. Selanjutnya, dianalisis dengan mereduksi dan mengklsifikasikan data. Setiap analisis dinarasikan secara deskriptif dan disimpulkan sesuai dengan pertanyaan rumusan masalahnya. Berdasarkan hasil identifikasi, penerapan pembelajaran daring selama pandemi Covid-19 di Paud Baiturrahman di Perum Bukit Cemara Tidar Krangbesuki Sukun Malang dilakukan melalui tahapan tujuan, perencanaan, materi, pelaksanaan, dan evaluasi. Pembelajaran daring menggunakan aplikasi Zoom dan WhatsApp yang tergabung dalam WhatsApp Group. Pelaksanaan pembelajaran daring yang dilaksanakan meliputi kegiatan pembukaan, kegiatan inti, permainan dan evaluasi pembelajaran daring yang berisi penilaian terhadap hasil kegiatan anak yang dikirim melalui video, foto, dan voicenote dan digunakan sebagai dasar penilaian harian, mingguan, bulanan, dan akhir semester.
\end{abstract}

Kata Kunci: Pembelajaran Daring, Paud Al-Quran Baiturrahman, Pandemi Covid19

\begin{abstract}
. in the pandemic covid 19 this educational institutions without exception to melakasanakan learning process in berani.But this need readiness teachers and the students in do.Especially in paud baiturrahman who is a early childhood education, is a challenge is a educate the children through berani.Readiness parents need to be accompanying putra-putrinya during the berani learning in the 19 covid pandemic. This study attempts to find out how the application of online learning in paud baiturrahman in perum evergreen hill tidar
\end{abstract}


krangbesuki breadfruit as poor education institutions in the pandemic covid-19. The subject of this research is the principal, teachers and parents.The primary data obtained through interviews with the subject in depth study that continued to observe and document as the initial processes. analysisNext, analyzed by reduction and mengklsifikasikan. dataEvery analysis dinarasikan in descriptive and concluded in accordance with the question is the problem. Formulation Based on the identification, the application of online learning for pandemic covid19 in early childhood in the evergreen state baiturrahman tidar krangbesuki breadfruit unfortunate done through the purpose, planning, material, the implementation of , and evaluation .Online learning there and use application whatsapp whatsapp group joined in .The online learning includes activities implemented the opening, core activities , games and online learning evaluation that contains an assessment of the results of the children are sent via video, a photograph, and voicenote daily assessment and used as a basis, weekly, monthly, and the end of the semester .

Keywords: online learning, paud al-quran baiturrahman, covid-19 pandemic

\section{BAB I PENDAHULUAN}

\subsection{Latar Belakang}

Dunia pendidikan harus senantiasa menyesuaikan perkembangan teknologi terhadap usaha dalam meningkatkan mutu pendidikan, terutama penyesuaian penggunaan teknologi informasi dan komunikasi bagi dunia pendidikan khususnya dalam proses pembelajaran. Implementasi pemanfaatan teknologi informasi dan komunikasi dalam dunia pendidikan salah satunya dapat diwujudkan melalui pembelajaran dalam jaringan (daring). Melalui pembelajaran daring tidak mengharuskan guru dan peserta didik saling bertatap muka.

Dewasa ini ancaman wabah virus Corona tengah dihadapi bangsa Indonesia, permasalahan besar sedang dihadapi bangsa ini sebagai musibah nasional. Pandemi Corona virus atau biasa disebut dengan Covid19 merupakan virus yang pertama kali di temukan di Wuhan, Hubei, Cina mulai dari akhir tahun 2019 hingga saat ini tahun 2020 dan telah mewabah keseluruh penjuru dunia salah satunya di Indonesia. 


\section{muhadasah \\ Jurnal Pendidikan Bahasa Arab \\ INSTITUT AGAMA ISLAM SUNAN KALIJOGO MALANG \\ P-ISSN 2622-6723 E-ISSN 2721-9488 \\ Volume 3, Nomor 1 Juni 2021}

Syndrom pernapasan akut berat corona virus 2 ( Sars Cov 2). ${ }^{1}$ Sejak pertama kali ditemukan kasus positif Covid-19 pada senin 2 Maret 2020 yang langsung diumumkan oleh Presiden Joko Widodo. Berbagai kebijakan pemerintah diambil guna mencegah penyebaran mata rantai virus Corona atau Covid19. Berbagai kebijakan yang diambil antara lain seperti, anjuran sosial distancing, physical distancing, memakai masker, anjuran mencuci tangan dengan sabun, dan pola hidup sehat. Selain itu beberapa daerah mengambil kebijakan untuk meliburkan siswa dari tingkat TK sampai dengan Perguruan Tinggi guna mencegah penyebaran mata rantai virus Corona atau Covid-19. 2

Kementrian Pendidikan dan kebudayaan (Kemendikbud) menerbitkan surat edaran Nomor 2 Tahun 2020 tentang pencegahan Covid-19 di lingkungan Kemendikbud dan Surat Edaran Nomor 3 Tahun 2020 tentang Pencegahan Covid-19 Pada satuan Pendidikan. Sedangkan pada tingkat Provinsi terdapat Surat Edaran Gubernur Jawa Tengah Nomor 440/0005942 Tentang Pencegahan Mata Rantai penyebaran Covid-19 maka kegiatan belajar mengajar mulai dari Pendidikan Anak Usia Dini hingga tingkat menengah atas diliburkan berlaku mulai dari tanggal 16 Maret sampai tanggal 29 Maret 2020 serta berubah sesuai dengan surat edaran terbaru. ${ }^{3}$

Himbauan dari Pemerintah sesuai dengan protokol kesehatan tentang prosedur pencegahan penyebaran virus Covid-19 semua kegiatan sekolah harus ditiadakan dan anak-anak belajar dari rumah dan semua guru harus bekerja dari rumah. Dengan penerapan Work From Home (WFH) maka semua pihak harus mematuhi aturan yang diberikan. Dengan adanya himbauan ini , guru agar tetap memantau dan memberikan kegiatan kepada murid melalui pembelajaran dalam jaringan (daring). ${ }^{4}$ Sebuah tantangan baru bagi guru Pendidikan Anak Usia dini, yang selama ini belum pernah menggunakan penerapan pembelajaran dalan jaringan untuk kegiatan belajar

\footnotetext{
${ }^{1}$ Susilo, dkk. Corona Virus Disease 2019: Tinjauan Literatur Terkini. Jurnal Penyakit Dalam Indonesia Vol. 7, No. 1. 2020

${ }^{2}$ https://infeksiemerging.kemkes.go.id

${ }^{3}$ https://www.kemdikbud.co.id

${ }^{4}$ https://id.m.wikipedia.org
} 
mengajar. Dengan adanya WFH pada jenjang Pendidikan Anak Usia Dini diharapkan guru tetap bisa memantau perkembangan dan kegiatan anak di rumah, dan terus berinteraksi dengan anak dan orang tua.

Berdasarkan permasalahan diatas, maka setiap lembaga sekolah dituntut untuk berinovasi dalam kegiatan belajar mengajar tanpa melakukan tatap muka terhadap peserta didiknya. Penerapan teknologi dan komunikasi dalam dunia pendidikan menjadi tidak asing lagi. Seperti yang telah disebutkan dalam kebijakan Ditjen PAUD Tahun 2019 mengenai pemanfaatan TI dalam pelaksanaan program PAUD Dikmas (MOOC, Anggun PAUD,Sahabat Keluarga). Oleh karena itu peneliti ingin mengetahui bagaimana penerapan pembelajaran daring ini berjalan di Paud Baiturrahman di Perum Bukit Cemara Tidar Karangbesuki Sukun Malang.

\subsection{Rumusan Masalah}

Bagaimana penerapan pembelajaran daring di Paud Baiturrahman di Perum Bukit Cemara Tidar Karangbesuki Sukun Malang

\subsection{Tujuan}

Untuk mengetahui bagaimana penerapan pembelajaran daring di Paud Baiturrahman di Perum Bukit Cemara Tidar Karangbesuki Sukun Malang

\section{METODE}

\subsection{Jenis dan Sumber Data}

Jenis penelitian yang digunakan adalah penelitian kualitatif dengan menggunakan penelitian lapangan (field research) yaitu penelitian yang dilakukan ditempat terjadinya gejala-gejala yang diteliti, data-data yang diperoleh dari hasil pengamatan baik secara langsung maupun tidak langsung (Zainal Arifin,2015:18).

Menurut Moleong yang dikutip oleh Haris Herdiansyah, penelitian kualitatif yaitu penelitian yang bermaksud memahami fenomena tentang apa yang dialami oleh subjek penelitian, misalnya perilaku, persepsi, motivasi, tindakan, dan lain sebagainya. Secara holistik dengan cara deskripsi dalam 


\section{muhadasah \\ Jurnal Pendidikan Bahasa Arab \\ INSTITUT AGAMA ISLAM SUNAN KALIJOGO MALANG \\ P-ISSN 2622-6723 E-ISSN 2721-9488 \\ Volume 3, Nomor 1 Juni 2021}

bentuk kata-kata dan bahasa pada suatu konteks khusus yang alamiah dan dengan memanfaatkan berbagai metode alamiah. ${ }^{5}$

Pendekatan penelitian kualitatif ini bersifat deskriptif. Penelitian deskriptif adalah pendekatan yang dimaksudkan untuk menyelidiki keadaan, kondisi atau hal lain-lain yang sudah disebutkan, yang hasilnya menghasilkan data deskriptif berupa kata-kata tertulis atau lisan dari orang-orang dan perilaku yang diamati. ${ }^{6}$

Penelitian deskriptif yang penulis lakukan adalah berupaya untuk menggambarkan bagaimana penerapan pembelajaran daring di Paud Baiturrahman Perum Bukit Cemara Tidar Karangbesuki Sukun Malang.

Dalam penelitian ini peneliti langsung mendatangi subjek penelitian sebagai informan. Secara teknis informan adalah orang yang dapat memberikan penjelasan yang lebih detail dan konferhensif mengenai apa, siapa, dimana, kapan, bagaimana,dan mengapa. Dimana subjek dan informan dalam penelitian ini adalah Kepala sekolah yaitu Ustadzah Jumriyah M,Pd.I, Guru Kelas yaitu Ustadzah Villa dan Ustadzah Niswah dan orang tua atau wali murid Paud Baiturrahman tentang bagaimana penerapan pembelajaran daring di Paud Baiturrahman Perum Bukit Cemara Tidar Karangbesuki Sukun Malang.

\subsection{Analisis Data}

Teknik analisis data penelitian ini dimulai dari lapangan, yakni dengan terjun ke lapangan. Proses pengumpulan data dilakukan dengan tahapan-tahapan sebagai berikut:

a. Reduksi data berarti merangkum, memilih hal-hal yang pokok, memfokuskan pada hal-hal yang penting dengan mencari tema dan polanya serta membuang hal atau data yang tidak digunakan. Reduksi data yang disajikan berupa hasil

\footnotetext{
${ }^{5}$ Haris Herdiansyah, Metodologi Penelitian Kualitatif untuk IImu-IImu Sosial, 2004, PT. Salemba Humanika, h. 9

${ }^{6}$ Suharsimi Arikunto, Prosedur Penelitian: Suatu Pendekatan Praktik. 2013, Jakarta: Rineka Cipta, hal. 3
} 


\section{muhadasah \\ Jurnal Pendidikan Bahasa Arab \\ INSTITUT AGAMA ISLAM SUNAN KALIJOGO MALANG \\ P-ISSN 2622-6723 E-ISSN 2721-9488 \\ Volume 3, Nomor 1 Juni 2021}

penelitian yang sudah dikumpulkan melalui sumber data yang sudah terkumpul. Data itu berupa kegiatan pembelajaran yang diterapkan selama pandemi Covid-19, mulai dari tahap persiapan, pelaksanaan dan evaluasi kegiatan

b. Penyajian data, setelah data dikumpulkan dan direduksi kemudian data disajikan, dapat dilakukan dalam bentuk uraian singkat dengan teks yang bersifat naratif. Penyajian data berupa data lengkap yang peneliti temukan secara langsung maupun tidak langsung. Data itu disajikan sesuai dengan fakta di lapangan, melalui jawaban pertanyaan dari narasumber, hasil observasi yang sudah dilaksanakan dan dokumentasi-dokumentasi kegiatan yang sudah dilakukan.

c. Kesimpulan yang berisi jawaban dari pertanyaan yang ada di rumusan masalah. Kesimpulan dari penelitian ini berupa deskripsi atau gambaran pembelajaran daring di Paud Baiturrahman Perum Bukit Cemara Tidar Karangbesuki Sukun Malang.

\section{PEMBAHASAN DAN HASIL PENELITIAN}

\subsection{TujuanPembelajaran Daring di Paud Baiturrahman}

Menurut Peraturan Menteri Pendidikan dan Kebudayaan Republik Indonesia Nomor 119 Tahun 2014 yang mengatur tentang Penyelenggaraan Pendidikan Jarak Jauh Jenjang Pendidikan Dasar dan Menengah disebutkan bahwa Pendidikan Jarak Jauh adalah Pendidikan yang peserta didik dan pembelajarannya menggunakan berbagai sumber belajar melalui penerapan prinsip-prinsip teknologi pendidikan/pembelajaran. Dengan tujuan untuk memfasilitasi peserta didik kegiatan pembelajaran yang bisa menjangkau secara luas peserta didik.

Kepala sekolah menuturkan bahwa tujuan penerapan pembelajaran daring di Paud Baiturrahman adalah untuk memfasilitasi peserta didik dan orang tua dalam belajar dan memantau performa peserta didik selama kegiatan di rumah. Dengan demikian tujuan penerapan pembelajaran daring di Paud Baiturrahman sudah 


\section{muhadasah \\ Jurnal Pendidikan Bahasa Arab \\ INSTITUT AGAMA ISLAM SUNAN KALIJOGO MALANG \\ P-ISSN 2622-6723 E-ISSN 2721-9488 \\ Volume 3, Nomor 1 Juni 2021}

selaras dengan peraturan Menteri Pendidikan dan Kebudayaan Nomor 19 Tahun 2014. Karena pembelajaran daring yang diterapkan sudah sesuai dengan unsur-usur peraturan yang ditetapkan dalam perundang-undangan. ${ }^{7}$

3.2 Perencanaan Pembelajaran Daring di Paud Baiturrahman.

Seperti yang dilansir oleh Tribun Jabar (senin, 23 Maret 2020) terdapat aplikasi rapat online yang dapat digunakan untuk melakukan Video Conference, antara lain adalah WhatsApp. ${ }^{8}$ Seperti yang diungkapkan Fitri (2019), bahwa Whatsapp Group (WAG) saat ini menjadi trend bagi guru dan wali siswa untuk berkomunikasi secara cepat dan efektif. Whatsapp Group bermanfaat sebagai penghubung harian antara guru dan orang tua secara langsung dan menyeluruh tentang aktivitas anak di sekolah. ${ }^{9}$ Menyampaikan informasi adalah bentuk dari komunikasi, sementara komunikasi berarti membangun interaksi antara orang tua dan guru Menurut Ustadzah Niswah dalam penerapan pembelajaran daring semua orang tua harus mengunduh aplikasi WA dan zoom karena pembelajaran daring di Paud Baiturrahman menggunakan WhatsApp Group (WAG) dan zoom. Dengan demikian perencanaan pembelajaran di Paud Baiturrahman sudah sesuai dengan pendapat para ahli, karena sudah memanfaatkan teknologi informasi dan komunikasi.

3.3 Materi Pembelajaran Daring Paud Baiturrahman

Berdasarkan Surat Edaran Mendikbud Nomor 4 Tahun 2020 tentang Pelaksanaan Kebijakan Pendidikan Dalam Masa Darurat Penyebaran Corona Virus Disease (Covid-19) mengatur tentang Belajar dari Rumah Melalui Pembelajaran Jarak Jauh, meliputi: 10

\footnotetext{
${ }^{7}$ Susilo, dkk. Corona Virus Disease 2019: Tinjauan Literatur Terkini. Jurnal Penyakit Dalam Indonesia Vol. 7, No. 1. 2020

${ }^{8}$ https://ebooks.gramedia.com/id/koran/tribun-jabar/23-mar-2020

${ }^{9}$ Fitri, Nur Lailatul. Pemanfaatan Grup Whatsapp Sebagai Media Informasi Proses Belajar Anak di KB Permata Bunda. Al Hikmah: Indonesian Journal Of Early Childhood Islamic Education Vol, 3 (2), 2019, PP. 151-166.

${ }^{10}$ Surat Edaran Nomor 4 Tahun 2020 "tentang Pelaksanaan Kebijakan Pendidikan Dalam Masa Darurat Penyebaran Coronavirus Disease (COVID-19)". Jakarta
} 
1. Memberikan pengalaman belajar yang bermakna bagi siswa, tanpa terbebani tuntutan menuntaskan seluruh capaian kurikulum kenaikan kelas ataupun kelulusan.

2. Memfokuskan pada pendidikan kecakapan hidup antara lain mengenai pandemi Covid-19.

3. Memberikan variasi aktivitas dan tugas pembelajaran belajar dari rumah antara siswa, sesuai minat, dan kondisi masing-masing.

4. Memberikan umpan balik terhadap bukti atau produk aktivitas belajar dari rumah yang bersifat kualitatif dan berguna bagi guru, tanpa diharuskan memberi skor/nilai kualitatif. Menurut kepala sekolah Paud Baiturrahman materi yang diberikan dalam pembelajaran daring antara lain:

a) Pengembangan karakter anak melalui kegiatan ketrampilan hidup (life skill) yang kegiatannya dilakukan sesuai dengan lingkungan di rumah.

b) Pengembangan fisik motorik melalui kegiatan bermain, olah raga pembiasaan penerapan hidup bersih dan sehat

c) Pengembangan nilai agama dan moral melalui pembiasaan beribadah sejak dini dengan keluarga,doa-doa harian, Al-Hadits

d) Pengembangan bahasa anak melalui kegiatan bercerita

e) Pengembangan sosial emosional anak melalui kegiatan kemandirian anak selama melaksanakan kegiatan.

f) Pengembangan kognitif anak melalui kegiatan bermain.

g) Pengembangan seni anak melalui kegiatan bernyanyi, menggambar .

Dengan demikian materi kegiatan yang diberikan dalam pembelajaran daring di Paud Baiturrahman sudah memenuhi standar pembelajaran sesuai Surat Edaran Mendikbud Nomor 4 Tahun 2020 tentang Pelaksanaan Kebijakan Pendidikan Dalam Masa Darurat Penyebaran Corona Virus Disease (Covid-19) mengatur tentang Belajar dari Rumah Melalui Pembelajaran Jarak Jauh. 


\section{muhadasah \\ Jurnal Pendidikan Bahasa Arab \\ INSTITUT AGAMA ISLAM SUNAN KALIJOGO MALANG \\ P-ISSN 2622-6723 E-ISSN 2721-9488 \\ Volume 3, Nomor 1 Juni 2021}

3.4 Pelaksanaan Pembelajaran Daring Paud Baiturrahman

National Association for the Education of Young Children (NAEYC) menyebutkan kegiatan yang memiliki kesesuaian perkembangan anak usia dini dapat diaplikasikan melalui program anak usia dini melalui: kurikulum, interkasi orang dewasa dengan anak-anak, hubungan antara rumah dan program, evaluasi.

Menurut Kepala sekolah bahwa pelaksanaan pembelajaran daring yang diterapkan tetap mengacu pada kurikulum sekolah yang sudah disesuaikan dengan masa darurat Covid-19. Kegiatan mengedepankan kegiatan bermain anak dan orang tua yang memfokuskan pada kegiatan keterampilan hidup yang ditemukan dalam kehidupan sehari-hari dengan orang tua. Pembiasaan pola hidup bersih dan sehat serta beribadah sejak dini sebagai pengembangan nilai agama dan moral pada anak. Dengan demikian pelaksanaan pembelajaran daring di Paud Baiturrahman sudah memuat program-program yang disesuaikan dengan prosedur pembelajaran dimasa darurat Covid-19.

3.5 Evaluasi Pembelajaran Daring Di Paud Baiturrahman

Menurut Meisels sebagaimana dikutip oleh Ardahani Dwi Kinasih dkk menjelaskan bahwa penilaian perkembangan anak dipakai untuk mengidentifikasi anak yang mempunyai sejumlah keterampilan spesifik dan/atau yang beresiko dan merencanakan kurikulum yang tepat bagi mereka .

Menurut kepala sekolah, Evaluasi yang diberikan oleh guru kepada anak yaitu melaui pengamatan dari tugas yang dikirim dalam bentuk foto,video dan rekaman suara. Penilaian juga dilakukan dengan orang tua melalui kegiatan sharing ilmu. Guru selalu aktif berkomunikasi dengan orang tua terkait dengan kegiatan bermain anak di rumah. Dengan pengamatan dan sharing ilmu itulah ditemukan hasil penilaian kepada masing-masing anak untuk menentukan kegiatan tersebut sudah di nilai berhasil atau masih perlu diulang. Dengan demikian evaluasi pembelajaran daring di Paud Baiturrahman sudah sesuai dengan National Association for the Education of Young Children (NAEYC) yang mengacu pada standar perkembangan anak usia dini. 


\section{muhadasah \\ Jurnal Pendidikan Bahasa Arab \\ INSTITUT AGAMA ISLAM SUNAN KALIJOGO MALANG \\ P-ISSN 2622-6723 E-ISSN 2721-9488 \\ Volume 3, Nomor 1 Juni 2021}

Dari hasil pengamatan guru terhadap tugas yang orang tua kirimkan di grup wa kelas inilah guru memberikan penilaiannya, apakah kompetensi intinya sudah tercapai apa belum. Selain itu, guru dapat melihat dari kegiatan anak apakah anak tersebut sudah mencapai kompetensi inti yang diharapkan atau anak masih perlu mengulang. Komunikasi dengan orang tua dalam sharing ilmu menjadi catatan khusus bagi guru dalam memberikan penilaian kepada anak, apakah anak tersebut masuk kedalam penilaian BB (Belum Berkembang, MB (Mulai Berkembang), BSH (Berkembang Sesuai Harapan), atau BSB (Berkembang Sangat Baik). Dari semuanya itu menjadi dasar guru untuk menilai anak baik untuk penilaian harian, migguan, bulanan dan akhir semester yang dilaporkan kepada orang tua.

\section{KESIMPULAN DAN SARAN}

\subsection{Kesimpulan}

Berdasarkan uraian di atas, maka penulis dapat mengambil kesimpulan mengenai penerapan pembelajaran daring selama pandemi virus Covid-19 di Paud Baiturrahman dilakukan melalui tahapan perumusan tujuan pembelajaran yaitu memberikan hak belajar kepada peserta didik selama pandemi Covid-19 untuk belajar dari rumah, memantau semangat peserta didik secara kontinue, memberikan kegiatan pemebelajaran yang lebih fleksible kepada peserta didik, dan memfasilitasi orang tua untuk sharing ilmu teradap perkembangan anak.

Perencanaan pembelajaran daring yang berisi dengan persiapan pembelajaran yang meliputi persiapan, pemberitahuan, mengunduh Aplikasi WA dan Zoom serta kesepakatan guru dan orang tua. Materi pembelajaran daring yang berisi tentang Pengembangan Karakter, Pengembangan FM, NAM, Bahasa, Sosem, Kognitif, dan Seni.

Pelaksanaan pembelajaran daring yang meliputi kegiatan pembukaan, kegiatan inti, teknik tampilan dan sharing ilmu. Dan yang terakhir tahapan evaluasi pembelajaran daring yang berisi penilaian terhadap hasil kegiatan anak yang dikirim melalui video, foto, dan voicenote dan digunakan sebagai dasar penilaian harian, mingguan, bulanan, dan akhir semester. 


\subsection{Saran}

Berdasarkan hasil penelitian pembelajaran daring ada beberapa saran yang perlu penulis sampaikan kepada beberapa pihak, yaitu:

1. Guru

Guru harus menjelaskan mengenai materi yang akan dijadikan bahan pembelajaran kepada orang tua sehingga orang tua. Guru harus lebih memperhatikan kondisi dan situasi lingkungan keluarga peserta didik dan mengambil jalan tengah. Guru selalu mengedukasi orang tua tentang pembelajaran anak usia dini adalah belajar sambil bermain, maka guru harus aktif dalam berkomunikasi dengan orang tua tentang pendampingan anak dalam setiap kegiatan.

\section{Orang tua}

Sebagai orang tua harus mampu berperan aktif dan terbuka melaporkan kepada guru mengenai informasi perkembangan anak selama di rumah. Orang tua harus melaporkan secara jujur melaporkan kepada guru dengan hasil belajar anak di rumah. Orang tua diharapkan dapat selalu memberikan edukasi kepada anak tentang masa pandemi Covid-19 yang sedang mewabah. Meyakinkan anak tentang alasan anak tidak diperkenankan berangkat kesekolah dan belajar di rumah. Orang tua juga harus tetap semangat sebagai guru di rumah agar anak semakin semangat dalam melaksanakan kegiatan bermain di rumah. 


\section{DAFTAR PUSTAKA}

Fitri, Nur Lailatul. 2019. Pemanfaatan Grup Whatsapp Sebagai Media Informasi Proses Belajar Anak di KB Permata Bunda. Al Hikmah: Indonesian Journal Of Early Childhood Islamic Education Vol, 3 (2), PP. 151-166.

Haris Herdiansyah, 2004. Metodologi Penelitian Kualitatif untuk Ilmu-Ilmu Sosial, PT. Salemba Humanika

https://ebooks.gramedia.com/id/koran/tribun-jabar/23-mar-2020

https://id.m.wikipedia.org

https://infeksiemerging.kemkes.go.id

https://www.kemdikbud.co.id

Suharsimi Arikunto, Prosedur Penelitian: Suatu Pendekatan Praktik. 2013, Jakarta: Rineka Cipta

Surat Edaran Nomor 4 Tahun 2020 "tentang Pelaksanaan Kebijakan Pendidikan Dalam Masa Darurat Penyebaran Coronavirus Disease (COVID-19)”. Jakarta

Susilo, dkk. 2020. Corona Virus Disease 2019: Tinjauan Literatur Terkini. Jurnal Penyakit Dalam Indonesia Vol. 7, No. 1. 